\title{
Determinan Perilaku Seks Pranikah Pada Remaja Pria (15-24 Tahun) di Indonesia (Analisis SDKI 2017)
}

\author{
(Determinan of Premarital Sex Behavior in Male Adolescents (15-24 Years) in \\ Indonesia (Analysis IDHS 2017)
}

\section{Ana Sandra Pidah, Ummi Kalsum, Hendra Dhermawan Sitanggang, Guspianto}

Program Studi Ilmu Kesehatan Masyarakat, Universitas Jambi, Jambi

\begin{abstract}
Abstrak
Perilaku seks pranikah merupakan salah satu masalah remaja yang sedang menuju dewasa. Transisi sosial dan budaya yang mengakibatkan remaja rentan terpengaruh dampak negatif. Tujuan penelitian menganalisis determinan perilaku seks pranikah pada remaja pria (15-24 tahun) di Indonesia tahun 2017. Penelitian ini menggunakan sebagian data SDKI tahun 2017 dengan desain Cross Sectional. Populasi penelitian yang digunakan adalah remaja pria (15-24 tahun) di Indonesia. Jumlah sampel sebanyak 12.453 remaja pria. Analisis bivariate menggunakan Chi-Square dan analisis multivariate menggunakan regresi logistik berganda model prediksi. Perilaku seks pranikah pada remaja pria sebanyak $7,7 \%$. Faktor yang berhubungan dengan perilaku seks pranikah pada remaja pria yaitu umur $(\mathrm{POR}=4,30 ; 95 \% \mathrm{CI}=3,63-$ $5,10$ ), pendidikan ( $\mathrm{POR}=1,42 ; 95 \% \mathrm{CI}=1,19-1,69)$, status pekerjaan ( $\mathrm{POR}=2,28 ; 95 \% \mathrm{CI}: 1,93-2,70$ ), status ekonomi keluarga ( $\mathrm{POR}=1,32 ; 95 \% \mathrm{CI}: 1,09-1,59)$, pendidikan orang tua ( $\mathrm{POR}=1,35$; 95\% CI: 1,02-1,77), pengetahuan kesehatan reproduksi ( $\mathrm{POR}=1,47$; 95\% CI: 1,09-1,97), pengetahuan alat kontrasepsi (POR=0,42;95\% CI: 0,34-0,51), sikap (POR=22,01;95\% CI: 18,23-26,55), gaya berpacaran $(\mathrm{POR}=59,27 ; 95 \%$ CI: 35,95-98,26), dan pengaruh teman sebaya (POR=11,96;95\% CI: 9,93-14,41). Faktor yang dominan tehadap perilaku seks pranikah remaja pria adalah gaya berpacaran $(\mathrm{POR}=20,51 ; 95 \%$ CI: $12,13-34,69)$ artinya remaja pria dengan gaya berpacaran berisiko memiliki risiko 20 kali untuk berperilaku seks pranikah. Untuk itu perlu adanya peningkatan edukasi pada remaja mengenai dampak gaya berpacaran yang berisiko serta pergaulan yang salah.
\end{abstract}

Kata Kunci: Perilaku Seks Pranikah, Remaja Pria, SDKI

\begin{abstract}
Premarital sexual behavior is one of the problems of adolescents who are heading towards maturity. Social and cultural transitions make adolescents vulnerable to negative impacts. The purpose of the study was to analyze the dominant determinants of premarital sex behavior in male adolescents (15-24 years) in Indonesia in 2017. This study uses some secondary data from 2017 Indonesian Demographic and Health Survey (IDHS) with a Cross-Sectional design study. The research population used male adolescents (1524 years) in Indonesia. The number of samples many as 12,453 male adolescent. Bivariate analysis using Chi-Square and multivariate analysis using multiple logistic regression predictive models. Premarital sex behavior in male adolescent was $7.7 \%$. Factors related to premarital sex behavior in male adolescent are age $(\mathrm{POR}=4.30 ; 95 \% \mathrm{CI}=3.63-5.10)$, education ( $\mathrm{POR}=1.42 ; 95 \% \mathrm{CI}=1.19-1.69)$, status occupation ( $\mathrm{POR}=2.28 ; 95 \%$ CI: 1.93-2.70), family economic status ( $\mathrm{POR}=1.32$; (95\% CI: 1.09-1.59), parental education (POR=1.35;95\% CI: 1.02-1.77), knowledge of reproductive health ( $\mathrm{POR}=1.47$;95\% CI: 1.091.97), knowledge of family planning ( $\mathrm{POR}=0,42 ; 95 \% \mathrm{CI}: 0,34-0,51$ ), attitude ( $\mathrm{POR}=22.01 ; 95 \% \mathrm{CI}$ : 18.23-26.55), dating style ( $\mathrm{POR}=59.27 ; 95 \%$ CI: 35.95-98.26), and peer influence (POR=11.96;95\% CI: 9.93-14.41). The most dominant determinant of premarital sex behavior in male adolescents was a dating style (POR=20,51;95\% CI: 12,13-34,69) meaning that male adolescents with a bold style are at risk of 20 times the risk for premarital sex behavior. There needs to be an increase in education for adolescents about the impact of risky dating styles and wrong associations.
\end{abstract}

Keywords:Premarital Sex Behavior, Male Adolescent, IDHS

Korespondensi: Ana Sandra Pidah

Email: Anasandrapidah@gmail.com 


\section{PENDAHULUAN}

Masa remaja merupakan individu yang berada pada masa peralihan, kelompok yang bukan lagi anak-anak dan belum dewasa. Masa ini ditandai dengan pertumbuhan dan perkembangan fisik, intelektual maupun psikologis disertai dengan pematangan seksual sehingga ketertarikan seksual terhadap lawan jenis cukup besar, hal ini seringkali mengarahkan remaja pada perilaku seks pranikah, perkembangan dan dorongan seksual dirasakan oleh remaja wajar secara biologis karena keingintahuan mencoba hal yang baru serta rasa penasaran yang besar ${ }^{1,2,3,4}$.

Berdasarkan hasil SDKI tahun 2007 dan 2012 perilaku seks pranikah cenderung meningkat, pada 2007 remaja dengan kelompok umur 15-19 tahun mengaku pernah melakukan hubungan seksual pranikah sebanyak 3,7\% meningkat menjadi 4,5\% pada tahun 2012 diikuti kelompok umur 20-24 tahun meningkat dari 10,5\% menjadi 14,6\%, sedikit mengalami penurunan pada SDKI tahun 2017 sebanyak 2\% pada remaja wanita dan $8 \%$ pada remaja pria diantaranya umur 15-19 tahun sekitar 3,6\% dan umur 20-24 tahun sekitar 14,0\% $5,6,7$

Menurut Survei RPJMN tahun 2017 Remaja yang pernah punya pacar dan pernah melakukan hubungan seksual mengalami kenaikan dalam satu tahun terakhir, dari 6\% menjadi $8 \%$ pada remaja pria ${ }^{7}$.Penelitian yang dilakukan Oktriyanto (2019) menggunakan data sekunder Survei Indikator RPJMN Tahun 2015 juga menyatakan terdapat 7,3\% remaja pria dan 2,3\% remaja putri pernah melakukan hubungan seks pranikah ${ }^{8}$.

World Health Organization (WHO) menyatakan pada tahun 2018 ada 1,5 milyar remaja di seluruh dunia, satu diantara lima orang di dunia merupakan remaja berusia 10-24 tahun $^{2}$. Pada tahun 2017 persentase penduduk Indonesia yang berusia 10-24 tahun sebanyak $25 \%$ dari 261,8 juta penduduk Indonesia. Hal ini menunjukkan besarnya populasi remaja di Indonesia yang merupakan sebagai modal pembangunan di masa depan negara. Namun di sisi lain hal itu juga mengindikasikan tingginya risiko masalah remaja, seperti perilaku seks yang dilakukan remaja sebelum menikah ${ }^{9}$.

Perilaku seks pranikah yang dilakukan remaja akan berdampak pada transmisi penularan penyakit menular seksual seperti HIV/AIDS, menurut WHO (2018) menyatakan diperkirakan 30\% dari 40 juta ODHA (yaitu 10,3 juta) merupakan orang muda berusia 15-24, adapun di Indonesia terjadi peningkatan jumlah kasus HIV/ AIDS di Indonesia setiap tahunnya, terdapat 48,300 kasus HIV pada 2017, dimana 20\% remaja usia 15-24 tahun terinfeksi HIV serta diantaranya terdapat 9,280 jumlah kasus $\operatorname{AIDS}^{10}$.

Dampak lain yang dapat ditimbulkan akibat dari perilaku seks pranikah yaitu kehamilan yang tidak diinginkan. Pada tahun 2017 terdapat 7\% pria dan 12\% wanita melaporkan pernah melakukan hubungan seksual dan berpengalaman kehamilan yang tidak diinginkan sehingga remaja terpaksa melakukan pernikahan dini untuk menutupi aib karena perilaku seks pranikah, dimana hal tersebut dapat mengarahkan pada perceraian ${ }^{11,12,13,5,14}$.

Selama beberapa dekade terakhir, aktivitas seksual pranikah di kalangan remaja meningkat dari waktu ke waktu secara global, khususnya di dunia Barat menjadi semakin dapat diterima dengan rata-rata $29 \%$ laki-laki dan $23 \%$ perempuan aktif secara seksual dan melakukan hubungan seks pranikah ${ }^{15}$. Negara-negara Asia Tenggara seperti Malaysia sebesar $37,9 \%$ melaporkan remaja aktif secara seksual diantaranya lebih dari setengahnya merupakan remaja pria ${ }^{16}$, kemudian Thailand diantara $24,1 \%$ prevalensi perilaku seks pranikah, terdapat 
$36,4 \%$ remaja laki-laki yang melakukan praktik seksual pranikah ${ }^{17}$, Brunei Darussalam melaporkan 11,3\% pernah melakukan hubungan seks panikah, 13,2\% di antara laki-laki dan Kamboja melaporkan proporsi remaja yang melakukan praktik hubungan seksual pranikah adalah $4,02 \%$ diantaranya $11,9 \%$ pada laki-laki ${ }^{18,19}$.

Fenomena seks pranikah di Indonesia pada kalangan remaja dapat ditemukan di perkotaan maupun perdesaan, tanpa memandang suku, agama atau bahkan latar belakang tingkat pendidikan ${ }^{3,20}$. Revolusi seksual ini, sering disebut sebagai tren yang merupakan salah satu ciri mencolok dari lingkungan sosiokultural Barat, sebagian remaja menganggap hal ini sebagai normatif dan bukan hal yang tabu lagi ${ }^{21,22}$.

Remaja laki-laki diketahui lebih banyak melakukan perilaku seks pranikah dibandingkan remaja perempuan, diketahui remaja laki-laki lebih banyak melakukan perilaku berisiko seperti merokok, minum keras dan NAPZA) yang berisiko terhadap kesehatan. Hal ini dikarenakan adanya perbedaan norma-norma sosial dan gaya hidup berdasarkan latar belakang budaya dan kemudahan aksebilitas dari pada perempuan dan berpeluang untuk berperilaku seksual, remaja laki-laki memiliki pergaulan sosial dan kebebasan yang lebih luas, serta pengawasan oleh orang tua tidak seketat pada remaja perempuan. Selain itu, proporsi perilaku berisiko lebih sedikit ditemukan pada remaja perempuan yang disebabkan karena norma sosial yang berlaku bahwa menghindari perilaku berisiko merupakan bagian dari identitas gender sebagai perempuan. Sebaliknya, melakukan perilaku berisiko merupakan bagian dari identitas gender sebagai laki-laki ${ }^{23,24}$.

Hasil survei SDKI Tahun 2017 juga menunjukkan terdapat 55\% remaja pria dan 1\% wanita merokok, $15 \%$ remaja pria dan $1 \%$ remaja wanita mulai minum minuman berakohol dan sebnayak $49 \%$ pria minum alkohol sampai mabuk, serta $5 \%$ pria menggunakan obat terlarang diantaranya $2 \%$ dengan cara dihisap dan $3 \%$ dengan cara diminum/ditelan, serta $8 \%$ pria dan $2 \%$ wanita yang pernah melakukan hubungan seksual saat pacaran ${ }^{7}$.

Menurut Survei RPJMN tahun 2017 Remaja yang pernah punya pacar dan pernah melakukan hubungan seksual mengalami kenaikan dalam satu tahun terakhir, dari $6 \%$ menjadi $8 \%$ pada remaja pria ${ }^{7}$. Penyebab terjadinya perilaku seks pranikah menurut teori precede-proceed pada remaja disebabkan oleh beberapa faktor yang meliputi faktor predisposing yang terdiri dari pengetahuan, sikap, dan ekonomi. Kemudian, faktor enabling terdapat adanya keterpaparan media dan gaya pacaran serta faktor reinforching peran teman sebaya $^{12}$.

Faktor-faktor yang dapat mendorong remaja untuk melakukan perilaku seks pranikah dikarenakan kurangnya pengetahuan tentang kesehatan reproduksi dan alat kontrasepsi serta akses yang buruk ke metode kentrasepsi termasuk kondom ${ }^{2,25}$.

Perkembangan teknologi yang semakin canggih dan berkembang, serta pengaruh pergaulan yang semakin luas akibat kemajuan teknologi yang pesat tersebut, banyak memengaruhi generasi muda yang semakin mudahnya orang mengakses berbagai informasi termasuk informasi tentang masalah seksual. Salah satu media yang mampu memberikan informasi secara cepat adalah internet. Menurut Kominfo (2017) melaporkan sebanyak 45\% masyarakat Indonesia sebagai penggunaa internet dari berbagai kalangan bisa mengakses internet termasuk remaja. Remaja bisa mengakses situs yang berhubungan dengan seks melalui internet, termasuk pornografi ${ }^{26,27}$. 
Berdasarkan ulasan permasalahan diatas penulis tertarik untuk melakukan penelitian mengenai determinan perilaku seks pranikah pada remaja pria (15-24 tahun) di Indonesia dengan menggunakan data SDKI 2017, yang bertujuan untuk menganalisis faktor determinan terhadap perilaku seks pranikah pada remaja pria (15-24 tahun) di Indonesia tahun 2017.

\section{METODE}

Jenis penelitian ini kuantitatif analitik dengan desain Cross-Sectional mengunakan sebagian data sekunder Survei Demografi dan Kesehatan Indonesia (SDKI) tahun 2017 dengan populasi seluruh remaja pria (15-24 tahun) di Indonesia tahun 2017, adapun jumlah sampel remaja pria pada SDKI 2017 sebanyak 13.079. Besar sampel yang diperoleh sebanyak 12.453 remaja pria setelah dieksklusi pada data missing, jawaban yang tidak lengkap, dan data yang tidak konsisten. Pada SDKI 2017 metode yang digunakan adalah Metode sampling dua tahap. Sedangkan peneliti menggunakan total sampling, dimana seluruh sampel sampel SDKI 2017 remaja pria usia 15-24 tahun yang didapat akan dijadikan sampel pada penelitian. Analisis data dilakukan dengan analisis complex sample, analisis bivariate menggunakan Chi-Square dan analisis multivariate menggunakan regresi logistik berganda model prediksi.

\section{HASIL PENELITIAN}

Berdasarkan Tabel 1 distribusi perilaku seks pranikah sebanyak 7,7\% remaja pria di Indonesia mengaku sudah pernah melakukan hubungan seks pranikah. Gambar 1 menunjukkan sebaran perilaku seks pranikah pada remaja pria di Indonesia lebih banyak ditemui pada Provinsi Sumatera Utara, Jawa Barat, Jawa Tengah, Jawa Timur, Bali, Nusa Tenggara Timur, dan Papua Barat.

Tabel 1 Distribusi Variabel Independen dan Variabel Dependen

\begin{tabular}{|l|c|c|}
\hline \multicolumn{1}{|c|}{ Variabel } & $\boldsymbol{F}$ & $\%$ \\
\hline Umur & 7.600 & 61 \\
\hline 15-19 Tahun & 4.853 & 39 \\
\hline 20-24 Tahun & & \\
\hline Pendidikan & 3.500 & 28,1 \\
\hline Rendah (<SMA) & 8.953 & 71,9 \\
\hline Tinggi ( $\geq$ SMA) & \\
\hline Status Pekerjaan & 6.191 & 49,7 \\
\hline Bekerja & 50,3 \\
\hline Tidak Bekerja & 6.262 & \\
\hline Status Ekonomi Keluarga \\
\hline Terbawah (Kuintil 1 dan 2) & 2.275 & 38,6 \\
\hline Menengah (Kuintil 3) & 7.614 & 20,2 \\
\hline Teratas (Kuintil 4 dan 5) & 2.563 & 41,2 \\
\hline Pendidikan Orang Tua & \\
\hline Rendah (<SD) & 6.090 & $48,9 \%$ \\
\hline Menengah (SMP \& SMA) & 5.116 & $41,1 \%$ \\
\hline Tinggi (PT) & 1.246 & $10 \%$ \\
\hline Tempat Tinggal & & \\
\hline Perkotaan & 6.775 & 54,4 \\
\hline Pedesaan & 5.677 & 45,6 \\
\hline Pengetahuan Kesehatan Reproduksi & \\
\hline Kurang & 10.655 & 85,6 \\
\hline Baik & 1.798 & 14,4 \\
\hline
\end{tabular}

\begin{tabular}{|l|c|c|}
\hline Variabel & $\boldsymbol{F}$ & $\%$ \\
\hline Pengetahuan Alat Kontrasepsi & \\
\hline Baik & 1.330 & 10,7 \\
\hline Kurang & 11.123 & 89,3 \\
\hline Sikap & 1.511 & 12,1 \\
\hline $\begin{array}{l}\text { Mendukung Seks } \\
\text { Pranikah }\end{array}$ & 10.942 & 87,9 \\
\hline Menolak Seks Pranikah & 7.831 & 62,9 \\
\hline Keterpaparan Media Internet & 2.877 & 23 \\
\hline Sering & 1.744 & 14 \\
\hline Jarang & \\
\hline Tidak Pernah & 6.331 & 50,8 \\
\hline Gaya berpacaran & 6.121 & 49,2 \\
\hline Berisiko & 2.366 & 19 \\
\hline Tidak Berisiko & 10.086 & 81 \\
\hline Pengaruh teman sebaya & & \\
\hline Ya & 961 & 7,7 \\
\hline Tidak & 11.492 & 92,3 \\
\hline Perilaku Seks Pranikah \\
\hline Melakukan \\
\hline Tidak Melakukan & \\
\hline
\end{tabular}

Sumber : Data Sekunder terolah, 2021 
Sebagian besar remaja pria di Indonesia berumur 15-19 tahun sebanyak $61 \%$. Mayoritas berpendidikan tinggi sebanyak $71,9 \%$, diketahui sebagian dari status pekerjaan yaitu tidak bekerja sebanyak 50,3\%. Melihat dari keadaan ekonomi keluarga berada pada keadaan ekonomi keluarga teratas $41,2 \%$, serta pendidikan orang tua yang rendah $48,9 \%$

Berdasarkan kakteristik wilayah/tempat tinggal lebih banyak remaja pria yang bertempat tinggal di wilayah perkotaan sebesar 54,4\% dengan sebagian besar responden memiliki pengetahuan yang kurang mengenai kesehatan reproduksi sebesar 85,6\% dan pengetahuan alat kontrasepsi sebesar $89,3 \%$. Selain itu responden menunjukan sikap menolak terkait perilaku seks pranikah sebanyak $87,9 \%$. Sebagian besar responden sering terpapar media internet sebesar $62,9 \%$ dan juga memiliki gaya berpacaran yang berisiko sebesar $50,8 \%$ serta tidak adanya pengaruh teman sebaya sebesar $81 \%$.

\section{PETA SEBARAN PERILAKU SEKS PRANIKAH PADA REMAJA PRIA 15-24 TAHUN DI INDONESIA}

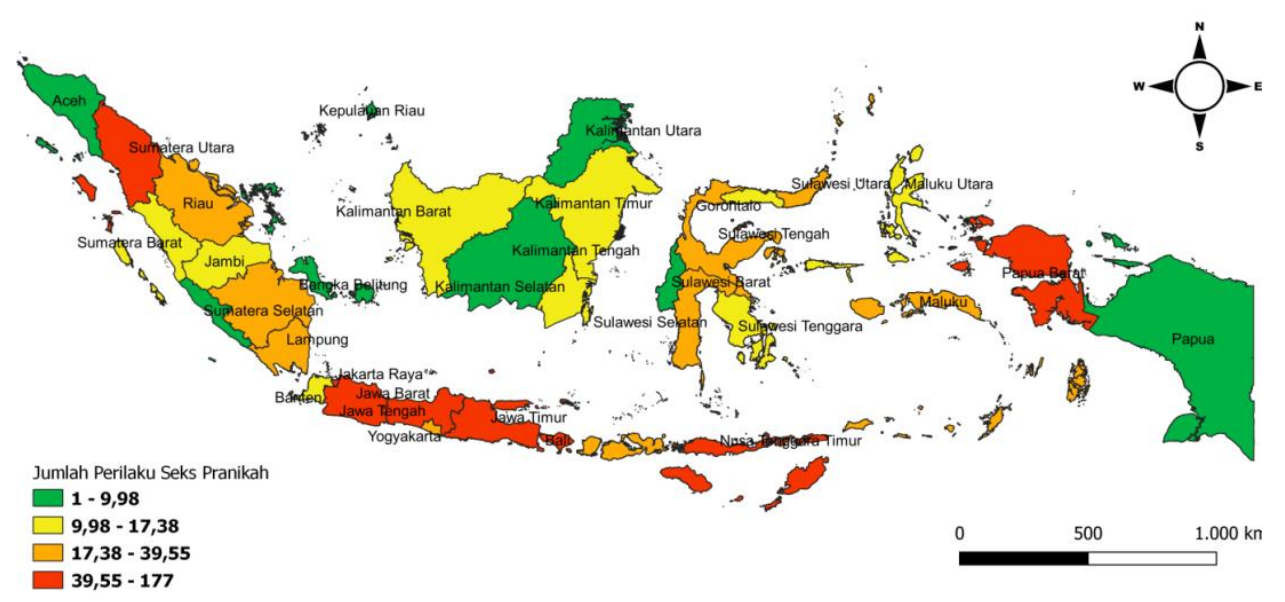

\section{Gambar 1 Persebaran Perilaku Seks Pranikah Remaja Pria di Indonesia}

Pada Tabel 2 berdasarkan analisis bivariate menunjukkan bahwa ada hubungan yang signifikan antara umur dengan perilaku seks pranikah pada remaja pria di Indonesia (POR= 4,305; 95\% CI: 3,631-5,104). Terdapat hubungan yang signifikan antara pendidikan dengan perilaku seks pranikah pada remaja pria di Indonesia (POR=1,425; 95\% CI : 1,196-1,698). Berdasarkan terdapat hubungan antara status pekerjaan dengan perilaku seks pranikah pada remaja pria di Indonesia, dan diperoleh pula nilai ( $\mathrm{POR}=2,289 ; 95 \% \mathrm{CI}: 1,938-2,703$ ). Melihat dari status ekonomi keluarga, ada hubungan antara status ekonomi keluarga terbawah dengan perilaku seks pranikah ( $\mathrm{POR}=1,323$; 95\% CI: 1,098-1,594), dan pada status ekonomi keluarga menengah juga ada hubungan yang signifikan antara status ekonomi keluarga menengah dengan perilaku seks pranikah pada remaja pria di Indonesia.

Berdasarkan pendidikan orang tua terdapat hubungan yang signifikan antara pendidikan orang tua rendah dengan perilaku seks pranikah pada remaja pria sedangkan pendidikan orang tua menengah tidak terdapat hubungan yang signifikan dengan perilaku seks pranikah pada remaja pria di Indonesia, dilihat dari wilayah/tempat tinggal tidak terdapat hubungan antara wilayah/tempat tinggal dengan perilaku seks pranikah pada remaja pria di Indonesia. 
Melihat dari pengetahuan kesehatan reproduksi menunjukkan bahwa ada hubungan yang signifikan antara pengetahuan kesehatan reproduksi dengan perilaku seks pranikah pada remaja pria di Indonesia (POR=1,473; 95\% CI: 1,099-1,976) Sama halnya dengan variabel pengetahuan alat kontrasepsi terdapat hubungan yang signifikan antara pengetahuan alat kontrasepsi dengan perilaku seks pranikah pada remaja pria di Indonesia (POR $=0,424 ; 95 \%$ CI;0,347-0,517). Berdasarkan sikap menunjukkan bahwa ada hubungan yang signifikan antara sikap dengan perilaku seks pranikah pada remaja pria di Indonesia.

Tabel 2 Faktor Determinan Perilaku Seks Pranikah pada Remaja Pria

\begin{tabular}{|c|c|c|c|c|c|c|}
\hline \multirow{3}{*}{ Variabel } & \multicolumn{4}{|c|}{ Perilaku seks pranikah } & \multirow{3}{*}{$P$-value } & \multirow{3}{*}{ POR (CI 95\%) } \\
\hline & \multicolumn{2}{|c|}{ Melakukan } & \multicolumn{2}{|c|}{$\begin{array}{c}\text { Tidak } \\
\text { melakukan } \\
\end{array}$} & & \\
\hline & $\mathbf{n}$ & $\%$ & $\mathbf{n}$ & $\%$ & & \\
\hline \multicolumn{7}{|l|}{ Umur } \\
\hline 20-24 Tahun & 684 & 14,1 & 4.170 & 85,9 & 0,000 & $4,305(3,631-5,104)$ \\
\hline 15-19 Tahun & 278 & 3,7 & 7.322 & 96,3 & & Ref \\
\hline \multicolumn{7}{|l|}{ Pendidikan } \\
\hline $\operatorname{Rendah}(<\mathrm{SMA})$ & 338 & 9,6 & 3.162 & 90,4 & 0,000 & $1,425(1,196-1,698)$ \\
\hline Tinggi $(\geq \mathrm{SMA})$ & 624 & 7 & 8329 & 93 & & Ref \\
\hline \multicolumn{7}{|l|}{ Status Pekerjaan } \\
\hline Bekerja & 654 & 10,6 & 5.537 & 89,4 & 0,000 & $2,289(1,938-2,703)$ \\
\hline Tidak Bekerja & 307 & 4,9 & 5.954 & 95,1 & & Ref \\
\hline \multicolumn{7}{|l|}{ Status Ekonomi Keluarga } \\
\hline Terbawah (Kuintil 1 dan 2) & 402 & 8,4 & 4.405 & 91,6 & 0,003 & $1,323(1,098-1,594)$ \\
\hline Menengah (Kuintil 3) & 227 & 9,0 & 2.288 & 91 & 0,004 & $1,435(1,123-1,835)$ \\
\hline Teratas (Kuintil 4 dan 5) & 332 & 6,5 & 4.798 & 93,5 & & Ref \\
\hline \multicolumn{7}{|l|}{ Pendidikan Orang Tua } \\
\hline Rendah $(<\mathrm{SD})$ & 115 & 9,3 & 1.131 & 90,7 & 0,031 & $0,740(0,563-0,973)$ \\
\hline Menengah (SMP \& SMA) & 418 & 8,2 & 4.699 & 91,8 & 0,301 & $0,870(0,669-1,132)$ \\
\hline Tinggi (PT) & 428 & 7 & 5.662 & 93 & & Ref \\
\hline \multicolumn{7}{|l|}{ Tempat Tinggal } \\
\hline Perkotaan & 484 & 7,6 & 5.868 & 92,4 & 0,413 & $0,926(0,771-1,113)$ \\
\hline Pedesaan & 384 & 8,2 & 4.332 & 91,8 & & Ref \\
\hline \multicolumn{7}{|c|}{ Pengetahuan Kesehatan Reproduksi } \\
\hline Kurang & 860 & 8,1 & 9.794 & 91,9 & 0,009 & $1,473(1,099-1,976)$ \\
\hline Baik & 101 & 5,6 & 1.697 & 94,4 & & Ref \\
\hline \multicolumn{7}{|c|}{ Pengetahuan Alat Kontrasepsi } \\
\hline Kurang & 764 & 6,9 & 10.359 & 93,1 & 0,000 & $0,424(0,347-0,517)$ \\
\hline Baik & 197 & 14,8 & 1.132 & 85,2 & & Ref \\
\hline \multicolumn{7}{|l|}{ Sikap } \\
\hline Mendukung Seks Pranikah & 623 & 41,2 & 887 & 58,8 & 0,000 & $22,006(18,236-26,555)$ \\
\hline Menolak Seks Pranikah & 338 & 3,1 & 10.603 & 96,9 & & Ref \\
\hline \multicolumn{7}{|l|}{ Keterpaparan Media Internet } \\
\hline Sering & 599 & 7,7 & 7.831 & 92,3 & 0,606 & $1,067(0,833-1,368)$ \\
\hline Jarang & 236 & 8,2 & 2.641 & 91,8 & 0,299 & $1,152(0,882-1,504)$ \\
\hline Tidak Pernah & 126 & 7,2 & 1.618 & 92,8 & & Ref \\
\hline \multicolumn{7}{|l|}{ Gaya Berpacaran } \\
\hline Berisiko & 943 & 14,9 & 5.388 & 85,1 & 0,000 & $59,275(35,957-98,263)$ \\
\hline Tidak Berisiko & 18 & 0,3 & 6.103 & 99,7 & & Ref \\
\hline \multicolumn{7}{|l|}{ Pengaruh teman sebaya } \\
\hline $\mathrm{Ya}$ & 651 & 27,5 & 1.715 & 72,5 & 0,000 & $11,967(9,936-14,413)$ \\
\hline Tidak & 310 & 3,1 & 9.776 & 96,9 & & Ref \\
\hline
\end{tabular}


Jika dilihat dari keterpaparan media internet menunjukkan tidak ada hubungan keterpaparan media internet dengan perilaku seks pranikah pada remaja pria di Indonesia. Pada gaya berpacaran terdapat hubungan yang signifikan antara gaya berpacaran dengan perilaku seks pranikah pada remaja pria di $(\mathrm{POR}=59,275$; 95\% CI: 35,957- 98,263). Hasil analisis hubungan antara teman sebaya dengan perilaku seks pranikah diperoleh hasil menunjukkan bahwa ada hubungan yang signifikan pengaruh teman sebaya dengan perilaku seks pranikah pada remaja pria di Indonesia. (POR $=11,967 ; 95 \%$ CI: 9,936-14,413). Dari hasil analisis multivariate menggunakan analisis regresi logistik dapat dilihat pada Tabel 3, diketahui bahwa variabel yang menjadi faktor dominan dalam perilaku seks pranikah pada remaja pria adalah gaya berpacaran. Hal ini dapat dilihat dari nilai prevalens odds ratio (POR) yang paling besar di antara variabel indrependen lainnya yaitu 20,519 (95\% CI: 12,134-34,697) setelah dikontrol variabel umur, tingkat pendidikan, status ekonomi keluarga, pendidikan orang tua, pengetahuan kesehatan reproduksi, pengetahuan alat kontrasepsi, sikap dan pengaruh teman sebaya.

Tabel 3 Model Akhir Analisis Multivariate Perilaku Seks Pranikah pada Remaja Pria di Indonesia

\begin{tabular}{|c|c|c|c|}
\hline Variabel & B & P-value & POR (95\% CI) \\
\hline \multicolumn{4}{|l|}{ Umur } \\
\hline 20-24 Tahun & 0,961 & 0,000 & $2,615(2,110-3,242)$ \\
\hline \multicolumn{4}{|l|}{ 15-19 Tahun (Reff) } \\
\hline \multicolumn{4}{|l|}{ Tingkat Pendidikan } \\
\hline Rendah & 0,522 & 0,000 & $1,685(1,313-2,163)$ \\
\hline \multicolumn{4}{|l|}{ Tinggi (Reff) } \\
\hline \multicolumn{4}{|l|}{ Status Ekonomi Keluarga } \\
\hline Terbawah & 0,464 & 0,000 & $1,590(1,237-2,044)$ \\
\hline Menengah & 0,592 & 0,000 & $1,807(1,319-2,478)$ \\
\hline \multicolumn{4}{|l|}{ Teratas (Reff) } \\
\hline \multicolumn{4}{|l|}{ Pendidikan Orang Tua } \\
\hline Rendah & $-0,821$ & 0,000 & $0,440(0,315-0,0,614)$ \\
\hline Menengah & $-0,367$ & 0,000 & $0,693(0,512-0,938)$ \\
\hline \multicolumn{4}{|l|}{ Tinggi (Reff) } \\
\hline \multicolumn{4}{|l|}{ Pengetahuan Kesehatan Reproduksi } \\
\hline Baik & 0,505 & 0,011 & $1,656(1,125-2,439)$ \\
\hline \multicolumn{4}{|l|}{ Kurang (Reff) } \\
\hline \multicolumn{4}{|l|}{ Pengetahuan Alat Kontrasepsi } \\
\hline Baik & $-0,349$ & 0,011 & $0,705(0,539-0,923)$ \\
\hline \multicolumn{4}{|l|}{ Kurang (Reff) } \\
\hline \multicolumn{4}{|l|}{ Sikap } \\
\hline \multirow{2}{*}{\multicolumn{4}{|c|}{$\begin{array}{l}\text { Mendukung Seks Pranikah } \\
\text { Menolak Seks Pranikah (Reff) }\end{array}$}} \\
\hline & & & \\
\hline \multicolumn{4}{|l|}{ Gaya Berpacaran } \\
\hline Berisiko & 3,021 & 0,000 & $20,519(12,134-34,697)$ \\
\hline \multicolumn{4}{|l|}{ Tidak Berisiko (Reff) } \\
\hline \multicolumn{4}{|l|}{ Pengaruh Teman Sebaya } \\
\hline Ya & 1,521 & 0,000 & $4,577(3,644-5,749)$ \\
\hline Tidak (Reff) & & & \\
\hline
\end{tabular}

Sumber : Data Sekunder terolah,2021 


\section{PEMBAHASAN}

\section{Hubungan Umur dengan Perilaku Seks Pranikah pada Remaja Pria}

Berdasarkan kelompok umur, remaja pria umur 20-24 tahun lebih tinggi melakukan perilaku seks pranikah dibandingkan dengan remaja pria kelompok umur 15-19 tahun. Penelitian ini juga menunjukkan bahwa remaja pria umur 20-24 tahun berisiko 2,6 kali untuk melakukan perilaku seks pranikah dibandingkan dengan remaja pria umur 15-24 tahun.

Penelitian ini sejalan dengan penelitian yang dilakukan oleh Suzanna (2018) didapatkan hasil bahwa ada hubungan antara umur dengan perilaku seksual. Peningkatan kadar hormon reproduksi dapat menyebabkan perubahan perilaku seksual remaja secara keseluruhan, sehingga berpengaruh terhadap peningkatan perhatian remaja pada lawan jenis ${ }^{28}$. Penelitian yang mendukung lainnya dilakukan oleh Lopes et al (2020) terdapat perbedaan perilaku seksual pranikah yang signifikan antara kelompok umur yang berbeda. Umur merupakan salah satu faktor yang mempengaruhi perilaku seks pranikah karena semakin meningkatnya usia maka semakin berkembangnya organ seksual ${ }^{29}$.

Saat remaja tumbuh dewasa, sistem saraf berkembang pesat dan memengaruhi kemampuan kognitif untuk mengembangkan kemampuan penalaran, yang memberikan tingkat penilaian moral dan kesadaran sosial yang baru ${ }^{29}$. Samakin meningkatnya usia remaja pria maka semakin mandiri dan semakin matangnya organ reproduksi sehingga berpengaruh terhadap dorongan seksual atau keinginan untuk kepuasan seksual didukung dengan pengetahuan mengenai kesehatan reproduksi yang rendah serta berpacaran dengan gaya pacaran yang berisiko sehingga berisiko untuk melakukan hubungan seksual sebelum adanya pernikahan.

\section{Hubungan Pendidikan dengan Perilaku Seks Pranikah pada Remaja Pria}

Berdasarkan analisis dari penelitian ini menunjukkan remaja pria dengan pendidikan rendah lebih banyak melakukan perilaku seks pranikah dibandingkan remaja pria dengan pendidikan tinggi. Penelitian ini juga menunjukkan bahwa remaja pria pendidikan rendah berisiko 1,6 kali untuk melakukan perilaku seks pranikah dibandingkan dengan remaja pria pendidikan tinggi. Penelitian ini sejalan dengan penelitan yang dilakukan Fauziah dan Maemunah (2017) bahwa terjadi hubungan yang kuat antara umur dan tingkat pendidikan terhadap perilaku seksual pranikah

Pendidikan secara teori mempengaruhi proses belajar dan tingkat pengetahuan seseorang termasuk dalam aspek kesehatan reproduksi. Pendidikan dapat membentuk pada pola pikir sehingga dapat memberikan wawasan yang luas, maka semakin tinggi pendidikannya maka akan semakin mudah menerima informasi dari berbagai sumber dan semakin baik pengetahuannya, bagitu pun sebaliknya pendidikan yang rendah akan menghambat remaja dalam mendapat informasi dan semakin rendah pula pengetahuan yang diperoleh, kurangnya informasi mengenai seksulaitas dan kesehatan reproduksi membuat remaja ingin mencoba-coba melakukan hubungn seksual tanpa mengetahui dampak yang akan ditimbulkan.

Remaja pria di Indonesia mayoritas $71,9 \%$ berpendidikan tinggi dan masih ada $7 \%$ diantaranya merupakan remaja dengan pendidikan tinggi yang melakukan seks pranikah. Hal ini dikarenakan kehidupan remaja yang saat dituntut untuk berpendidikan tinggi sehingga pernikahan harus ditunda sedangkan perkembangan reproduksi dan seksual pada masa remaja masuk ke tahap pematangan dan penuh gejolak. Seharusnya semakin tinggi pendidikan 
seseorang, semakin baik pengetahuannya. Pengetahuan tersebut akan berpengaruh dalam membentuk sikap dan perilaku sehingga semakin tinggi pendidikan seseorang akan memiliki perilaku yang positif ${ }^{30}$.

\section{Hubungan Status Pekerjaan dengan Perilaku Seks Pranikah pada Remaja Pria}

Berdasarkan status pekerjaan, dimana remaja pria yang bekerja lebih banyak melakukan perilaku seks pranikah dibandingkan remaja pria yang tidak bekerja. Penelitian ini juga menunjukkan bahwa remaja pria yang bekerja berisiko 2,289 kali untuk melakukan perilaku seks pranikah dibandingkan dengan remaja pria tidak bekerja. Namun setelah dilakukan uji multivariate bersama dengan variabel lain, secara statistik tidak terdapat hubungan yang signifikan antara status pekerjaan dengan perilaku seks pranikah pada remaja pria. Sejalan dengan penelitian Hidiarti menemukan bahwa tidak terdapat hubungan antara status pekerjaan dengan perilaku seks pranikah, dimana remaja yang bekerja mengisi waktu luangnya dengan hal-hal yang positif ( $\mathrm{OR}=0,156 ; 95 \% \mathrm{CI}$ : 0,643-1,446).

Sebagian besar remaja pria bekerja dikarenakan status ekonomi keluarga yang rendah, akan tetapi apabila remaja pria yang bekerja maupun yang tidak bekerja sama-sama memiliki pengetahuan kesehatan reproduksi yang kurang, sehingga memiliki peluang yang sama untuk melakukan seks pranikah tergantung dari bagaimana individu remaja itu sendiri dalam menyikapi perilaku seks pranikah dan juga pengetahuan serta gaya berpacaran yang dilakukan nya.

\section{Hubungan Status Ekonomi Keluarga dengan Perilaku Seks Pranikah pada Remaja Pria}

Adapun berdasarkan status ekonomi keluarga menunjukkan bahwa remaja pria dengan status ekonomi keluarga terbawah cenderung lebih banyak melakukan perilaku seks pranikah dibandingkan remaja pria dengan status ekonomi keluarga teratas, dimana remaja pria status ekonomi terbawah mempunyai risiko 1,3 kali lebih tinggi untuk melakukan perilaku seks pranikah dibandingkan dengan status ekonomi keluarga tinggi, begitu juga dengan status ekonomi keluarga menengah bahwa remaja pria mempunyai risiko 1,4 kali lebih tinggi untuk melakukan perilaku seks pranikah dibandingkan remaja pria status ekonomi tinggi.

Penelitian ini sejalan dengan penelitian yang dilakukan Puspasari berdasarkan tingkat kekayaan terdapat hubungan yang signifikan terhadap perilaku seksual, dimana remaja sangat miskin berisiko 2 kali untuk melakukan perilaku seksual dibandingkan remaja yang sangat kaya $(\mathrm{POR}=2,06 ; 95 \% \mathrm{CI}: 1,525-2,781)^{31}$. Penelitian ini juga sesuai dengan penelitian yang dilakukan Farida bahwa remaja yang tumbuh dalam lingkungan miskin cenderung berperilaku seks pranikah lebih awal, dimana remaja dengan status sosial ekonomi rendah 3 kali lebih tinggi melakukan perilaku seksual remaja dibandingkan remaja dengan status sosial ekonomi tinggi (POR=3,07; 95\% CI: $1,63-5,75)^{32}$. Penelitian ini tidak sesuai dengan pernelitian yang dilakukan Getie menyatakan bahwa terdapat hubungan antara indeks kekayaan dengan perilaku seks pranikah lebih tinggi pada indeks kekeyaan yang tinggi (AOR=1,4 95\% CI: 1-1,9), sedangkan pada remaja indeks kekayaan menengah tidak terdapat hubungan yang signifikan dengan perilaku seks ${ }^{33}$.

Berdasarkan hasil penelitian dan teori dapat disimpulkan bahwa remaja dari sosial ekonomi terendah, menengah sama-sama memiliki peluang untuk tersentuh pada perilaku pacaran hingga seks pra nikah, yang memberatkan akibat tersebut karena gaya hidup yang 
semakin meningkat menjadi pemicu bagi remaja yang memiliki status ekonomi keluarga rendah untuk melakukan apa saja termasuk melakukan seksual pra nikah..

\section{Hubungan Pendidikan Orang tua dengan Perilaku Seks Pranikah pada Remaja Pria}

Berdasarkan pendidikan orang tua remaja pria dengan pendidikan orang tua tinggi dan menengah lebih banyak melakukan perilaku seks pranikah dibandingkan remaja pria dengan pendidikan orang tua rendah. dimana pendidikan orang tua bersifat protektif terhadap perilaku seks pranikah.

Sejalan dengan peneltian Wibisono (2017) adanya korelasi antara tingkat pendidikan dengan perilaku seksual pada remaja sebesar 0,442 , yang berarti nilai korelasi yang positf maka semakin tinggi tingkat pendidikan orang tua, maka perilaku seksual pada remaja akan menjadi buruk ${ }^{34}$. Sedangkan menurut Yolanda (2017) pendidikan orang tua baik ayah maupun ibu tidak berhubungan dengan sikap maupun perilaku seks pranikah, dikarenakan pendidikan seksualitas sangat jarang diberikan orang tua karena berdasarkan budaya setempat pembahasan mengenai seksualitas masih dianggap sensitif ${ }^{35}$.

Pendidikan orang tua tinggi justru juga berada pada status ekonomi teratas dan cenderung mempunyai pekerjaan yang baik sehingga membuat orang tua sibuk bekerja yang mengakibatkan memburuknya perilaku yang dilakukan remaja dan berisiko seks pranikah pada remaja. Pendidikan orang tua yang tinggi justru kebutuhan dan fasilitasnya terpenuhi, sehingga dikarenakan orang tua sibuk bekerja mengakibatkan kurangnya pengawasan dan perhatian dari orang tua sehingga remaja sering mengakses internet yang dapat berpengaruh negatif. Serta kurangnya informasi terkait seksualitas dan kesehatan reproduksi dari orang tua.

\section{Hubungan Wilayah/Tempat Tinggal dengan Perilaku Seks Pranikah pada Remaja Pria}

Melihat dari wilayah/tempat tinggal remaja pria dengan wilayah/tempat tinggal perdesaan lebih banyak melakukan perilaku seks pranikah dibandingkan remaja pria yang bertempat tinggal di wilayah perkotaan karena adanya kemajuan teknologi yang berkembang pesat hingga ke daerah pedesaan dengan kemudahan dalam mengakses berbagai informasi menyebabkan tingginya perilaku seks pranikah pada remaja di daerah perdesaan. Berdasarkan statistik menunjukkan tidak terdapat hubungan yang signifikan antara wilayah/tempat tinggal dengan perilaku seks pranikah.

Hal ini sejalan dengan penelitian yang dilakukan oleh Pusmaika dan Riano menunjukkan bahwa tidak ada pengaruh antara tempat tinggal dengan perilaku seksual remaja ( $\mathrm{OR}=1,22$ 95\% CI: 0,73-0,92), dikarenakan gaya hidup hidup remaja di perkotaan dan pedesaan sangat sulit untuk dibedakan saat ini, disebabkan kemajuan teknologi yang sudah merambat di pedesaan ${ }^{36}$. Namun, hasil penelitian ini berbanding terbalik dengan penelitian yang dilakukan oleh Ma'ruf di Indonesia yang menyatakan bahwa wilayah tempat tinggal memiliki hubungan yang signifikan dengan perilaku seksual remaja dimana remaja perkotaan berisiko 18 kali lebih tinggi niat melakukan hubungan seksual pranikah dibandingkan remaja dipedesaan ${ }^{37}$.

\section{Hubungan Pengetahuan Kesehatan reproduksi dengan Perilaku Seks Pranikah pada Remaja Pria}

Masih banyak remaja pria dengan pengetahuan yang kurang mengenai kesehatan reproduksi di Indonesia. dimana pengetahuan kesehatan reproduksi yang kurang lebih banyak melakukan perilaku seks pranikah dibandingkan remaja pria dengan pengetahuan kesehatan 
reproduksi baik. Penelitian ini juga menunjukkan bahwa remaja pria pengetahuan kesehatan reproduksi kurang berisiko 1,473 kali untuk melakukan perilaku seks pranikah dibandingkan dengan remaja pengetahuan kesehatan reproduksi baik.

Penelitian ini sejalan dengan penelitian yang dilakukan Murdianingsih et al 2020 terdapat hubungan yang signifikan antara pengetahuan kesehatan reproduksi dengan perilaku seks pranikah, yang mana pengetahuan kesehatan reproduksi merupakan faktor dominan dari perilaku seks pranikah (POR=38,26 95\% CI: 7,526-194,56) ${ }^{38}$.

Menurut Farida pengetahuan merupakan faktor yang paling berhubungan dengan perilaku seksual remaja $(\mathrm{POR})=4,35$ (CI 2,28-8,28) Namun penelitian berbeda dengan penelitian yang dilakukan Sari dkk bahwa pengetahuan kesehatan reproduksi memiliki hubungan dengan perilaku seksual, akan tetapi sangat lemah dengan diperoleh nilai contingency coefficient sebesar $0,175^{39}$.

Pengetahuan merupakan salah satu faktor yang mempengaruhi terjadinya perilaku. Masa remaja dengan rasa penesaran dan keingintahuan yang tinggi dan tidak diimbangi dengan pengetahuan yang cukup mengenai kesehataan reproduksi dapat menempakan remaja pada situasi berbahaya dan meyimpang. Jika remaja pria memiliki pengetahuan yang baik terkait pengetahuan kesehatan reproduksi, maka remaja pria cenderung berperilaku sesuai dengan apa yang telah diketahuinya. Pengetahuan yang dimaksud adalah pengetahuan remaja mengenai perubahan fisik yang dialami dan masa pubertas.

Hasil analisis lanjut juga memperoleh bahwa hampir sebagian remaja pria tidak mengetahui perempuan dapat hamil dengan sekali berhubungan seksual $(48,3 \%)$, dan pengetahuan kesehatan reproduksi yang kurang lebih banyak ditemui didaerah pedesaan $(87,9 \%)$, dimana sampai saat ini pengetahuan mengenai seksualitas masih menjadi hal yang tabu. Untuk itu perlu adanya edukasi mengenai kesehatan reproduksi pada remaja.

\section{Hubungan Pengetahuan Alat Kontrasepsi dengan Perilaku Seks Pranikah pada Remaja Pria}

berdasarkan pengetahuan alat kontrasepsi hasil analisis menunjukkan pengetahuan alat kontrasepsi bersifat protektif terhadap perilaku seks pranikah dimana remaja pria dengan pengetahuan alat kontrasepsi baik justru lebih banyak melakukan perilaku seks pranikah dibandingkan remaja pria dengan pengetahuan alat kontrasepsi yang kurang.

Sejalan dengan penelitian yang dilakukan Hossen (2020) bahwa pengetahuan yang memadai tentang kontrasepsi remaja berhubungan positif dengan perilaku seks pranikah, dimana remaja dengan pengetahuan baik cenderung melakukan hubungan seks pranikah 2.3 kali lebih banyak dari remaja yang tidak berpengetahuan baik (95\% CI: 1,455-3,639) ${ }^{25}$. Begitu juga penelitian yang dilakukan Wandasari pada daerah pedesaan dan perkotaan di Indonesia bahwa remaja yang menerima pengetahuan mengenai alat kontrasepsi justru melakukan hubungan seks pranikah dibandingkan remaja yang tidak menerima pengetahuan mengenai alat kontrasepsi $(r=-0,003 \text { dan } r=-0,012)^{40}$.

Pengetahuan mengenai alat kontrasepsi dapat mengatasi masalah-masalah sosial, baik itu kependudukan dan kesehatan dan juga membantu remaja menunda perkawinan dan kehamilan, menjarangkan kelahiran, menghindari kehamilan yang tidak diinginkan dan mencegah terjadinya IMS. Penundaan perkawinan dan kelahiran pada usia dini memberikan kesempatan kepada remaja untuk dapat memperoleh pekerjaan ataupun melanjutkan pendidikan ke jenjang yang lebih tinggi. 
Hasil analisis lanjut juga menemukan bahwa remaja pengetahuan alat kontrasepsi yang baik tetapi malah pengetahuan kesehaan reproduksi kurang $(68,2 \%)$ dan sebagian besar remaja pengetahuan mengenai alat kontrasepsi yang baik memiliki gaya berpacaran yang berisiko sebesar $67,6 \%$. Sebagian lebih remaja mengetahui alat kontrasepsi jenis injeksi atau suntik (64\%), sebagian besar remaja sudah mengetahaui alat kontrasepsi jenis pil (76,1\%), dan sebanyak 88,9\% remja mengetahui kondom sebagai alat konttrasepsi. Hal ini dikarenakan remaja yang pengetahuan alat kontrasepsi baik, mempunyai rasa percaya diri dan aman untuk melakukan hubungan seksual tanpa rasa takut dan khawatir akan kejadian yang tidak diinginkan.

Alat kontrasepsi saat ini di Indonesia memang masih menjadi kontroversi, disatu sisi remaja yang telah aktif secara seksual berhak untuk mencegah kehamilan ataupun mengurangi risiko kesehatan dari perilaku seksualnya. Namun disisi lain, dengan adanya program KB di indonesia remaja dapat dengan mudah memperoleh alat kontrasepsi salah satunya di supermarket.

Secara mental hal itu dapat mendorong remaja melakukan hubungan seks tanpa khawatir resiko kehamilan, tentunya hal ini akan membuat remaja akan membuat remaja lebih permisif dan mudah tuntuk gonta-ganti pasangan. Untuk itu perlu adanya penegasan edukasi hanya untuk pasangan yang sudah menikah sehingga tidak terjadi kesalahpahaman persepsi.

\section{Hubungan Sikap dengan Perilaku Seks Pranikah pada Remaja Pria}

Berdasarkan analisis dari penelitian ini menunjukkan bahwa remaja pria dengan sikap mendukung terhadap perilaku seks pranikah lebih banyak melakukan perilaku seks pranikah dibandingkan remaja pria dengan sikap menolak. Penelitian ini juga menunjukkan bahwa remaja pria sikap mendukung berisiko 21,6 kali untuk melakukan perilaku seks pranikah dibandingkan dengan remaja pria sikap menolak.

Penelitian ini Sejalan dengan penelitin yang dilakukan Ayu dkk bahwa sikap merupakan kecenderungan spesifik individu untuk bereaksi atau bertindak berdasarkan pengalaman, sikap juga sebagai faktor risiko untuk terbentuknya perilaku, sikap yang negatif akan cenderung melakukakan perilaku sekss pranikah. Hasil peneltian menemukan terdapat hubungan antara sikap dengan perilaku seks pranikah, dimana remaja dengan sikap negatif berisiko 7 kali untuk melakukan perilaku seks pranikah daripada remaja dengan sikap positif (POR: 7,240 ; 95\% CI : 3,953-13,264) ${ }^{12}$.

Hasil analisis lanjut juga membuktikan bahwa remaja mempunyai sikap mendukung terhadap seks pranikah dikarenakan pengetahuan kesehatan reproduksi yang kurang. Adapun sikap yang paling dominan terhadap perilaku seks pranikah adalah remaja setuju melakukan perilaku seks pranikah karena sama-sama senang dengan nilai $\mathrm{p}$-value $=0,000(\mathrm{POR}=4,375$ 95\% CI: 2,760-6,934) dan diikuti oleh sikap terhadap perilaku seks pranikah karena saling cinta ( $p$-value $=0,000 ; \mathrm{POR}=3,306 ; 95 \% \mathrm{CI}: 1,946-5,611)$.

Sikap mendukung terhadap seks pranikah lebih banyak ditemui pada kelompok umur 20-24 tahun $(15,9 \%)$ dengan pendidikan rendah $(15,6 \%)$, didukung oleh status ekonomi keluarga yang rendah $(! 4,2 \%)$, pengetahuan mengenai alat kontrasepsi yang baik $(18,1 \%)$ dan memiliki gaya berpacaran berisiko $(19,2 \%)$ serta remaja yang terpengaruh teman sabaya juga menunjukkan 30,3\% memiliki sikap mendukung terhadap perilalu seks pranikah. 
Berdasarkan hasil dan teori diketahui sikap merupakan faktor determinan perilaku pacaran dan seksual pranikah. Sikap adalah suatu bentuk evaluasi atau reaksi perasaan mendukung (favorable) atau tidak mendukung (unfavorable) terhadap suatu objek. Sikap mempunyai arah, yaitu setuju atau tidak setuju terhadap suatu objek ${ }^{41}$. Sehingga sikap merupakan awal mula dalam dalam pembentuk perilaku, sikap yang mendukung atau mendukung akan berisiko menghasilkan perilaku yang negatif pula.

Sebanyak $11,3 \%$ remaja pria di Indonesia mendukung terhadap perilaku seks pranikah dan diantaranya 41,2\% melakukan hubungan seks pranikah. Sehingga perlu bagi orang tua atau pihak sekolah untuk tetap memberikan pengetahuan yang benar menyangkut perilaku pacaran dan seksual serta remaja mencari pengetahuan ataupun informasi tentang seks dari sumber yang benar sehingga dapat berdampak positif bagi remaja itu sendiri.

\section{Hubungan Keterpaparan Media Internet dengan Perilaku Seks Pranikah pada Remaja Pria}

Hasil penelitian ini menunjukkan bahwa tidak terdapat hubungan antara keterpaparan media internet dengan perilaku seks pranikah pada remaja pria. Internet merupakan sumber informasi yang mudah diakses dan dapat mempengaruhi pengetahun, sikap, dan perilaku seseorang. Jika remaja tidak mendapatkan informasi dan pengetahuan yang cukup tentang kesehatan reproduksi maka dapat membuat remaja rentan berperilaku seks pranikah, sebaliknya jika remaja mendapat informasi yang cukup dan informasi yang benar dari sumber terpercaya mengeni seksualiats.

Sejalan dengan penelitian yang dilakukan Mesra tidak terdapat hubungan media terhadap perilaku seks pranikah p-value 1,000 (POR 0,964 (95\% CI: 0,512-1,814). ${ }^{42}$ Farida juga menyatakan bahwa tidak terdapat hubungan bermakna antara paparan media pornografi dengan perilaku seksual remaja. Hal ini berarti bahwa remaja yang terpapar media pornografi dan yang tidak terpapar media pornografi sama-sama tidak pernah melakukan hubungan seksual ataupun sebaliknya ${ }^{32}$. Kemungkinan ada faktor lain yang memiliki pengaruh lebih besar terhadap perilaku seksual remaja seperti pengetahuan, teman sebaya dan ketaatan beragama. Penelitian Hidiarti (2017) menyatakan paparan media massa yang tinggi berisiko 1,3 kali untuk melakukan perilaku seksual berisiko, akan tetapi hal ini tidak terbukti signifikan karena paparan media tergantung bagaimana pengunaannya ( $p$-value $=0,182$; OR=1,338; $95 \%$ CI: 0,835-2,001) $)^{43}$.

Keterpaparan media internet dapat memberikan dampak yang positif maupun dampak yang negatif, tergantung bagaimana remaja menggunakannya. Dampak negatif yang dapat menyebabkan remaja pria berperilaku seks pranikah dikarenakan mengakses mengakses situs-situs porno yang sangat mudah ditemui diinternet, tentunya hal ini menjadi perhatian khusus karena dapat merusak moral, sikap dan perilaku remaja. selain itu dampak positif dari kerterpaparan media internet dapat mengakses informasi dan pengetahuan mengenai kesehatan reproduksi perilaku seks pranikah.

\section{Hubungan Gaya Berpacaran dengan Perilaku Seks Pranikah pada Remaja Pria}

Berdasarkan analisis dari penelitian ini menunjukkan remaja pria dengan gaya berpacaran berisiko lebih banyak melakukan perilaku seks pranikah dibandingkan remaja pria dengan gaya berpacaran tidak berisiko. Penelitian ini juga menunjukkan bahwa remaja pria gaya berpacaran yang berisiko memiliki risiko 20 kali untuk melakukan perilaku seks pranikah dibandingkan dengan remaja pria gaya berpacaran tidak berisiko. 
Sejalan dengan peneltian yang dilakukan Qamariah (2020), bahwa terdapat hubungan antara pacar dengan perilaku seks pranikah. Faktor yang mempengaruhinya karena makna pacaran persepsi yang salah dari makna pacaran.. Sejalan juga dengan penelitian Restiyana dkk bahwa terdapat hubungan yang signifikan antara status pacaran berhubungan dengan perilaku seksual remaja (OR=4,755 95\% CI: 2,207-10,244) ${ }^{44}$.

Menurut BKKBN (2019) Perilaku pacaran menjadi pintu terjadinya free sex. Perilaku berpacaran mulai dari berpegangan tangan, berpelukan, berciuman, disentuh payudara, dicium leher. Adapun alasan remaja berpacaran karena merasa saling mencintai, saling suka, saling memiliki, merasa tidak ingin ditinggalkan. Keinginan selalu bersama dengan pacar, mencari tempat berduaan merupakan salah satu awal mula pemicu dari perilaku seks $\operatorname{pranikah}^{45}$.

Hampir sebagian remaja di Indonesia memiliki gaya berpacaran berisiko sebanyak $50,8 \%$ dan diantaranya 14,9\% melakukan perilaku seks pranikah. Adapun diantara remaja yang melakukan gaya berpacaran berisiko diantaranya banyak dilakukan oleh remaja umur 20-24 tahun $(70,7 \%)$ yang bekerja $(60,7 \%)$ dan didukung dengan status ekonomi keluarga menengah dan teratas yang banyak mempunyai gaya berpacaran berisiko $(53,3 \%)$ dan $52,8 \%$ ) serta pendidikan orang tua yang menengah dan tinggi lebih banyak remaja pria yang berpacaran dengan gaya berisiko (52,6\% dan 50,5\%), dimana gaya berpacaran berisiko lebih banyak ditemui di daerah perkotaan (53\%) dan sering terpapar media internet (56\%), serta faktor dipengaruhi teman sebaya juga merupakan faktor yang mempengaruhi remaja pria dalam melakukan gaya berpacaran berisiko.

Hasil analisis lanjut juga menemukan terdapat $13,5 \%$ remaja pria yang status berpacaran melakukan perilaku seks pranikah, diantara remaja pria yang pernah berpegangan tangan terdapat $10,1 \%$ pernah melakukan seks pranikah, sementara remaja pria yang pernah berpelukan, ada sebanyak 15,2\% melakukan perilaku seks pranikah, sama halnya dengan remaja pria pernah berciuman bibir terdapat $22,3 \%$ pernah melakukan seks pranikah, sedangkan remaja pria yang pernah meraba atau diraba sebanyak 33,7\% melakukan perilaku seks pranikah, diantara remaja yang gaya berpacaran berisiko, remaja yang pernah meraba meraba/diraba merupakan faktor dominan terhada perilaku seks pranikah.

\section{Hubungan Pengaruh Teman Sebaya dengan Perilaku Seks Pranikah pada Remaja Pria}

Berdasarkan analisis dari penelitian ini menunjukkan remaja pria dengan terpengaruh teman sebaya lebih banyak melakukan perilaku seks pranikah dibandingkan remaja pria dengan tidak terpengaruh teman sebaya. Penelitian ini juga menunjukkan bahwa remaja pria terpengaruh teman sebaya berisiko 4,6 kali untuk melakukan perilaku seks pranikah dibandingkan dengan tidak terpengaruh teman sebaya.

Teman sebaya atau teman bergaul sangat berperan dalam remaja untuk berperilaku, hal ini dikarenakan lingkungan teman sebaya dapat membawa ke arah yang positif seperti dalam berprestasi dan berkreasi maupun ke arah negatif seperti dalam tuntutan untuk berkencan, berpenampilan dll. Remaja rentan untuk meniru dan mengikuti perilaku temannya dikarenakan remaja banyak mengabiskan waktu bersama dan bertukar pikiran pada temannya serta dalam mengambil keputusan untuk berperilaku.

Penelitian sejalan dengan penelitian yang dilakukan Suparmi pada remaja pria dan wanita di Indonesia, remaja yang mengabiskan waktu bersama dapat menularkan perilaku menyimpang pada temannya, penelitian ini juga menemukan terdapat hubungan antara peran 
teman sebaya dengan perilaku seksual pranikah, dimana hasil penelitian ini menyatakan remaja pria yang memiliki teman sebaya sudah melakukan hubungan seksual berisiko 11 kali untuk melakukan perilaku seksual (POR: 10,63 ; (95\% CI : 7,26-15,57) $)^{46}$.

Penelitian yang dilakukan Puspita dkk juga menyatakan remaja lebih banyak memilih menghabiskan akhir pekan bersama teman ketimbang keluarga, terkadang lebih nyaman membicarakan seksualitas dengan teman sebaya dibanding orang lain serta terkadang melihat gambar/video porno karena diperlihatkan teman, hasil statistik menunjukan ada hubungan antara peran teman sebaya yang mendukung dengan perilaku seksual pranikah berisiko sig=0,001 ( $\mathrm{sig}<0,05)^{47}$. Aprianti juga mengemukakan bahwa faktor teman sebaya merupakan faktor dominan terhadap perilaku seks pranikah, dimana teman yang berperan negatif brisiko 2,743 kali lebih tinggi melakukan hubungagan seks pranikah dibandingkan teman sebbaya berperan positif ${ }^{20}$. Namun penelitian ini tidak sejalan dengan yang dilakukan Elfina dkk tidak ada hubungan antara interaksi teman sebaya dengan perilaku seks pranikah pada remaja SMKN 1 Baweng Semarang ${ }^{48}$.

Analisis lanjut menunjukkan 55,2\% remaja mempunyai teman yang pernah melakukan seks pranikah dan sebanyak 34,5\% remaja merasa termotivasi untuk melakukan perilaku seks pranikah juga, dimana banyak ditemui di wilayah pedesaan $(19,2 \%)$ dan remaja berusia 20 24 tahun lebih banyak terpengaruh oleh teman sebayanya untuk melakukan perilaku seks pranikah $(28,7 \%)$. Remaja yang terpangaruh teman sebaya sebagian besar juga memiliki gaya berpacara berisiko $(85,1 \%)$, hal ini dikarenakan remaja lebih banyak berkonsultasi dengan temannya mengenai tren berpacaran dan gaya berpacaran yang dilakukan.

Teman sebaya juga dianggap penting oleh remaja karena pada masa ini remaja cenderung terjadi pergeseran lingkungan sosial dari keluarga ke lingkungan teman sabaya, sehingga remaja banyak mendapatkan informasi dan nasehat-nasehat dari teman sebayanya tanpa mempertimbangkan baik atau buruknya, seperti masukan bahwa pacaran adalah hal yang wajar dilakukan dan apabila tidak memiliki pacar, maka akan dianggap ketinggalan zaman, mengajak menonto porno. Teman sebaya sering mengajak menonton film pornografi, dikarenakan remaja merasa penting untuk mendapatkan informasi seksua ${ }^{49}$.

\section{Faktor Dominan Perilaku Seks Pranikah pada Remaja Pria di Indonesia}

Hasil analisis multivariate pada penelitian ini faktor dominan yang paling mempengaruhi perilaku seks pranikah pada remaja pria di Indonesia adalah remaja pria dengan gaya berpacaran berisiko, dimana remaja pria dengan gaya berpacaran berisiko meningkatkan risiko untuk berperilaku seks pranikah sebesar 20,198 kali dibandingkan remaja pria dengan gaya berpacaran tidak berisiko setelah dikontrol variabel umur, tingkat pendidikan, status ekonomi keluarga, pendidikan orang tua, pengetahuan kesehatan reproduksi, pengetahuan alat kontrasepsi, sikap dan pengaruh teman sebaya.

Penelitian ini sejalan dengan penelitian yang dilakukan Puspasari bahwa gaya berpacaran yang intim memicu terjadinya perilaku seks pranikah, hasil analisis menemukan bahwa remaja yang gaya berpacaran inti berisiko 24 kali untuk untuk melakukan perilaku seks pranikah dibandingkan remaja yang tidak berpacaran atau pun remaja gaya berpacaran tidak intim (OR : 24,11 ; 95\% CI : 8,920-65,210). Penelitian ini juga didukung oleh penelitian yang dilakukan Harnani pada anak jalanan di Pekanbaru bahwa status berpacaran merupakan faktor dominan yang mempengaruhi perilaku seks pranikah, dimana anak jalanan 
yang berpacaran berisiko 39 kali lebih tinggi untuk melakukan seks pranikah dibandingkan anak jalanan yang tidak berpacaran (POR=39,414 95\% CI: 7,846-197,531) ${ }^{51}$.

Namun penelitian ini berbeda dari penelitian yang dilakukan Umaroh di Indonesia bahwa faktor yang paling mempengaruhi perilaku seks pranikah adalah faktor sikap dimana sikap yang tidak baik berisiko 2 kali untuk melakukan perilaku seksual pranikah pada remaja dibandingkan remaja dengan sikap baik (POR: 2,129 (95\%CI : 1,963-2,309). Berbeda juga dengan penelitian yang dilakukan Nurhayati, peran teman sebaya menjadi faktor dominan yang mempengaruhi perilaku seks pranikah, dimana peran teman sebaya yang buruk berisiko 4 kali melakukan perilaku seksual pranikah dibandingkan peran teman sebaya yang baik. (PR: 3,891 (95\% CI : 1,752-8,643) $)^{31}$.

Analisis lanjut diketahui bahwa gaya berpacaran yang paling dominan terhadap perilaku seks pranikah adalah gaya berpacaran meraba/diraba dengan nilai $\mathrm{POR}=29,172$ $(20,220-42,086)$ yang artinya gaya berpacaran yang meraba atau diraba berisko 29 kali untuk melakukan seks pranikah, diikuti oleh gaya berpacaran berciuman dengan nilai $\mathrm{POR}=3,969$ 95\% CI: 2,437-6,462 artinya remaja gaya berpacaran yang berciuman berisiko 4 kali untuk melakukan perilaku seks pranikah dan gaya berpacaran berpelukan diperoleh nilai $\mathrm{POR}=2,974$ (1,547-5,717) berarti remaja pria yang berpelukan berisiko 2,9 kali untuk melakukan perilaku seks pranikah dibandingkan remaja pria yang gaya berpacaran tidak berpelukan. Adapun faktor dominan penyebab remaja berpacaran berisiko dipengaruhi oleh teman sebaya dengan diperoleh nilai $\mathrm{POR}=5,165$ (4,417-6,039) artinya remaja terpengaruh teman sebaya berisiko 5 kali lebih tinggi untuk memiliki gaya berpacaran berisiko, dibandingkan remaja yang tidak terpengaruh teman sebaya.

Pacaran merupakan jembatan untuk terjadinya kontak fisik yang dapat menimbulkan rangsanggan yang dapat mengakibat remaja melakukan perilaku seks pranikah, dikarenakan sebangai bentuk untuk menunjukkan kasih sayang dapat dimulai dari tertarik, mulai berpacaran, berpegangan tangan, berpelukan, berciuman, hingga meraba dan menimbulkan rangsangan untuk melakukan hubungan seksual sebelum adanya pernikahan. Gaya berpacaran yang berisiko dapat bertahap dan menimbulkan ketagihan untuk melakukannya dan keingintahuan yang lebih. Namun untuk tidak menutup kemungkinan remaja dengan gaya berpacaran tidak berisiko berkembang menjadi berisiko dipengaruhi oleh berbagai faktor baik dari remaja itu sendiri maupun dipengaruhi oleh faktor luar juga.

\section{KESIMPULAN DAN SARAN}

Remaja pria yang mengaku pernah melakukan perilaku seks pranikah sebesar 7,7\%. Terdapat hubungan antara umur, pendidikan, status pekerjaan, status ekonomi keluarga, pendidikan orang tua, pengetahuan kesehatan reproduksi, pengetahuan alat kontrasepsi, sikap, gaya berpacaran, pengaruh teman sebaya, dengan perilaku seks pranikah pada remaja pria di Indonesia dan tidak terdapat hubungan antara wilayah atau tempat tinggal dan keterpaparan media internet dengan perilaku seks pranikah remaja pria di Indonesia. Faktor dominan yang paling berpangaruh tehadap perilaku seks pranikah remaja pria adalah gaya berpacaran.

Disarankan bagi institusi kesehatan yang terkait untuk dapat melakukan intervensi pada sasaran misalnya dengan membuat program edukasi dan promosi berupa konten yang menarik melalui media sosial seperti instagram, tiktok dll. remaja diharapkan dapat selektif 
memilih teman maupun pasangan, bagi peneliti selanjutnya untuk dapat melakukan penelitian lebih lanjut mengenai faktor yang dominan terhadap perilaku seks pranikah dangan cara wawancara mendalam dan menambah variabel yang belum diteliti seperti, kepercayaan dan pengamalan religius, gaya hidup, serta peran orang tua.

\section{DAFTAR PUSTAKA}

1. Alfiyah N, Solehati T, Sutini T. Gambaran Faktor-Faktor yang Berhubungan dengan Perilaku Seksual Pranikah pada Remaja SMP. J Pendidik KEPERAWATAN Indones. 2018 Dec 31;4(2).

2. World Health Organization. Orientation Programme on Adolescent Health for Health-care Provider Handout New Modules. 2018. 6 p.

3. Mishbahatul E, Has M, Safitri AN, Kusumaningrum T. The Effect of Education by Using Snakes and Ladders as a Medium on Adolescents Knowledge and Attitudes in the Prevention of Premarital Sex in Junior High School [Internet]. Vol. 11, Systematic Reviews in Pharmacy. 2020 [cited 2020 Oct 26]. Available from: https://www.sysrevpharm.org/fulltext/196-1598670825.pdf

4. Winingsih W, Solehati T, Hernawaty T. Hubungan Konsep Diri Dengan Perilaku Seksual Beresiko Pada Remaja. J Ilm Permas J Ilm STIKES Kendal. 2019;9(4):343-52.

5. Badan Pusat Statistik (BPS). Badan kependudukan dan Keluarga Berencana Nasional (BKKBN). Kementerian Kesehatan (Kemenkes). dan ICF internasional . Survei Demografi Dan Kesehatan : Kesehatan Reproduksi Remaja 2017 [Internet]. 2017. Available from: http://www.dhsprogram.com.

6. Badan Pusat Statistik (BPS). Badan kependudukan dan Keluarga Berencana Nasional (BKKBN). Kementerian Kesehatan (Kemenkes). dan ICF internasional 2003. Survei Demografi Dan Kesehatan : Kesehatan Reproduksi Remaja 2012. 2012.

7. Badan kependudukan dan Keluarga Berencana Nasional (BKKBN). Survei Kependudukan, Keluarga Berencana, Kesehatan Reproduksi Remaja dan Pembangunan Keluarga di Kalangan Remaja Indonesia Tahun 2017. Jakarta; 2017.

8. Oktriyanto O, Alfiasari A. Dating and Premarital Sexual Inisiation on Adolescence in Indonesia. J Kesehat Masy [Internet]. 2019 [cited 2020 Oct 21];15(1):98-108. Available from: http://journal.unnes.ac.id/nju/index.php/kemas

9. Badan Pusat Statistik (BPS). Statistik Indonesia 2018. 2018.

10. Kementrian Kesehatan RI. General situation of HIV/AIDS and HIV test. Pusat Data dan Informasi Kementrian Kesehatan RI. 2018. p. 1-12.

11. Wahyuni S, Fahmi I. Determinan Perilaku Seksual Pra Nikah Remaja Pria di Indonesia Hasil SDKI. Euclid [Internet]. 2019 Jul 26 [cited 2020 Oct 14];6(2):177. Available from: http://jurnal.unswagati.ac.id/index.php/Euclid/article/view/2201

12. Ayu SM, Sofiana L, Wibowo M, Gustiana E, Setiawan A. Predisposing, Enabling and Reinforcing Factors of Premarital Sex Behavior in School Adolescents. J Kesehat Masy. 2019;15(1):29-38.

13. Hastuti P, Aini FN. Gambaran Terjadinya Pernikahan Dini Akibat Pergaulan bebas. Ris Kesehat. 2016;5(1):11-3.

14. Anjarwati. Increasing the minimum age of marriage program to improve maternal and child health in Indonesia. AIP Conf Proc. 2017;090003(1868):1-6.

15. Dahal M, Subedi RK, Khanal S, Adhikari A, Sigdel M, Baral K, et al. Prevalence and possible risk factor of Premarital Sexual Behaviour among Nepalese Adolescents 23 Nepal Running title: PSB in Nepalese adolescents [Internet]. 2020 [cited 2020 Oct 26]. Available from: https://www.researchsquare.com/article/rs-78183/latest.pdf

16. Renjhen P, Low WY, Tong WT. Determinants of sexual activity, awareness, and use of 
contraception among Malaysian college students. Australas Med J. 2016;9(5):78-86.

17. Srijaiwong S, Sindhu S, Ratinthorn A, Viwatwongkasem C. Factors influencing sexual behaviors among Thai adolescents. J Popul Soc Stud. 2017;25(3):171-93.

18. Pengpid S, Peltzer K. Sexual behaviour and its correlates among adolescents in Brunei Darussalam. Int J Adolesc Med Health. 2021;33(1):1-7.

19. Mai V, Kittisuksathit S. Factors influencing pre-marital sexual intercourse among unmarried young individuals in Cambodia. Makara J Heal Res [Internet]. 2019 Dec 1 [cited 2020 Nov 13];23(3):143-9. Available from: https://scholarhub.ui.ac.id/mjhr

20. Aprianti A, Nursal D, Kesehatan YP-M, 2020 undefined. Reinforcing Factor Perilaku Seks Pranikah pada Remaja SMA Favorit di Kota Padang. journal.unhas.ac.id [Internet]. [cited 2020 Oct 12]; Available from: https://journal.unhas.ac.id/index.php/mkmi/article/view/9046

21. Jayati MR. Faktor yang Berpengaruh terhadap Perilaku Seksual Remaja di Smk Kesehatan Haji Sumatera Utara Tahun 2019 1. 2019.

22. Rahardjo W. Perilaku Seks Pranikah pada Mahasiswa: Menilik Peran Harga Diri, Komitmen Hubungan, dan Sikap terhadap Perilaku Seks Pranikah. J Psikol. 2017;44(2):139.

23. Mahmudah M, Yaunin Y, Lestari Y. Faktor-Faktor yang Berhubungan dengan Perilaku Seksual Remaja di Kota Padang. J Kesehat Andalas. 2016;5(2):448-55.

24. Wahdini M, Indraswari N, Susanti AI, No JS, Geulis C, Kaler KC, et al. Faktor-Faktor Yang Berhubungan Dengan Perilaku Berisiko Pada Remaja Di Jawa Barat Tahun 2018. J BKKBN. 2018;1-19.

25. Hossen MA, Quddus AHG. Prevalence and Determinants of Premarital Sex Among University Students of Bangladesh. Sex Cult [Internet]. 2020;(0123456789). Available from: https://doi.org/10.1007/s12119-020-09768-8

26. Kementerian Komunikasi dan Informasi Republik Indonesia. Survei Penggunaan TIK serta Implikasinya terhadap Aspek Sosial Budaya Masyarakat. 2017.

27. Fitriani I. Hubungan perilaku mengakses situs pornografi dengan perilaku seksual pranikah remaja. 2017; Available from: http://digilib.unisayogya.ac.id/2412/1/NASKAH PUBLIKASI.pdf

28. Suzanna, Rusmaniar D. Hubungan Karakteristik , Sikap dan Media Informasi dengan Perilaku Seksual Mahasiswa di Kota Palembang Tahun 2016. J 'Aisyiyah Med. 2018;1(1):74-89.

29. Lopes SJ, Anakaka DL, Aipipidely D. Adolescent Premarital Sexual Behavior. J Heal Behav Sci. 2020;2(4):335-46.

30. Rahmad Hidayat A, Nurhayati I. Peran Orang Tua dalam Pencegahan Perilaku Sex Pranikah pada Remaja di Bantul [Internet]. Vol. 5, formilkesmas.respati.ac.id. 2020 [cited 2020 Oct 21]. Available from: http://formilkesmas.respati.ac.id

31. Puspasari, Sukamdi O, Emilia. Paparan informasi kesehatan reproduksi melalui media pada perilaku seksual pranikah: analisis data survei demografi kesehatan Indonesia 2012. Ber Kedokt Masy. 2017;30(1):31-6.

32. Farida Y. Hubungan Pengetahuan, Status Sosial Ekonomi, Pola Asuh Orang Tua, Paparan Media Pornografi dengan Perilaku Seksual Remaja (Studi survey analitik di SMU Negeri Kabupaten Karawang). J Kebidanan. 2016;5(1):18-29.

33. Getie KS, Kassie A, Woldie M. Prevalence and Determinants of Premarital Sexual Practice Among Youths in Ethiopia: Further analysis of the Ethiopian Demographic and Health Survey. 2020;1-23.

34. Wibisono ZN, Yuliadi I, Suwito D. Hubungan Tingkat Pendidikan Orang Tua dan Status Ekonomi dengan Perilaku Seksual Remaja Di SMA Negeri 2 Surakarta. Nexus Kedokt Komunitas. 2017;6(2):92-100.

35. Yolanda R, Kurniadi A, Tanumihardja TN. Faktor-Faktor yang Berhubungan dengan Sikap Remaja Terhadap Perilaku Seksual Pranikah di Kecamatan Siberut Selatan , Kepulauan 
Mentawai Tahun 2018. J Kesehat Reproduksi. 2019;10(1):69-78.

36. Pusmaika R, Riono P. Pengaruh Wilayah Tempat Tinggal Terhadap Perilaku Potensial Seks Berisiko Pada Remaja Di Indonesia (Analisis Data SDKI-KRR 2012). J Gend Behav. 2019;17(2):1-19.

37. Maruf MA, Richter K, Soonthorndada A. Hubungan Karakteristik Demografik Dengan Niat Melakukan Hubungan Seksual Pranikah Pada Remaja Laki-Laki Indonesia. MPPKI (Media Publ Promosi Kesehat Indones Indones J Heal Promot. 2018;1(3).

38. Murdiningsih, Rohaya, Hidun S, Ocktariyana. The effect of adolescent reproductive health education on premarital sexual behavior. 2020;9(4):227-32.

39. Sari DN, Darmana A, Muhammad I. Pengaruh Faktor Predisposisi, Pemungkin, dan Pendorong Terhadap Perilaku Seksual di SMA Asuhan Daya Medan. J Kesehat Glob. 2018;1(2):53.

40. Wandansari DA. Disparitas Pengalaman Seksual Remaja Menurut Status Wilayah Perdesaan dan Perkotaan di Indonesia Tahun 2012 (Analisis Data SDKI 2012). 2016;

41. Mariani NN, Murtadho SF. Peran Orang Tua, Pengaruh Teman Sebaya, Dan Sikap Berhubungan Dengan Perilaku Seksual Pranikah Pada Siswa-Siswi SMA Negeri 1 Jamblang Kabupaten Cirebon. J Care. 2018;6(2):116-30.

42. Mesra E, Fauziah. Pengaruh Teman Sebaya Terhadap Perilaku Seksual Remaja. J Ilm Bidan. 2016;1(2):34-41.

43. Hindiarti YI. Faktor-Faktor Yang Berhubungan Dengan Perilaku "X " Kota Yogyakarta Tahun 2015 Factors Associated With Sexual Behavior in Adolescent Workers in Shopping Area " X " Yogyakarta in 2015. J Med Respati. 2017;12(3):39-51.

44. Restiyana S, Utari N, Yuspita. Faktor-Faktor Yang Mempengaruhi Perilaku Seksual Remaja dan Implikasinya. J Psychol Perspect [Internet]. 2019;2(1):49-57. Available from: http://www.ncbi.nlm.nih.gov/pubmed/10765874

45. Suazini ER, Humaeroh L. Identifikasi Kasus Unwanted Pregnancy pada Remaja: Studi Fenomenologi. J Kesehat PERINTIS (Perintis's Heal Journal). 2021;7(2):44-58.

46. Suparmi S, Isfandari S. Peran Teman Sebaya terhadap Perilaku Seksual Pranikah pada Remaja Laki-Laki dan Perempuan di Indonesia. Bul Penelit Kesehat. 2016;44(2):139-46.

47. Puspita IA, Agusybana F, Dharminto D. Hubungan Penggunaan Media Sosial dan Peran Teman Sebaya dengan Perilaku Seksual Berisiko di SMK Kota Surakarta. J Kesehat. 2020;7(3):111-8.

48. Elfina R, Choiriyyah Z, Rosyidi MI. Hubungan Interaksi Teman Sebaya Dengan Perilaku Seks Pra Nikah Pada Remaja Di Smk Negeri 1 Bawen Kab. Semarang. J Keperawatan dan Kesehat Masy Cendekia Utama. 2018;7(2):166.

49. Rahmawati NI, Suminar DR, Soedirham O, Ilmu F, Politik I, Airlangga U. Hubungan Personal Remaja Dengan Pelaksanaan Pendidikan Karakteroleh Orang Tua Dalamupaya Pencegahan Perilaku Seksual Pranikah Di Kabupaten Jember. J Kesehat Reproduksi [Internet]. 2019;9(2):149-57. Available from: http://garuda.ristekbrin.go.id/documents/detail/1699277

50. Harnani Y, Alamsyah A. Premarital Sex among Adolescent Street Children in Pekanbaru. 2018;7(1):22-6. 